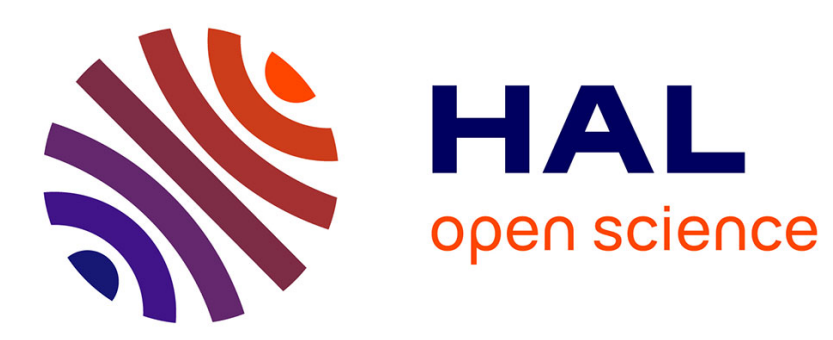

\title{
Ancient Blueprints: New Prospects and Interpretations in Light of Recent Discoveries
}

\author{
Jeanne Capelle
}

\section{To cite this version:}

Jeanne Capelle. Ancient Blueprints: New Prospects and Interpretations in Light of Recent Discoveries. Philip Sapirstein; David Scahill. New Directions and Paradigms for the Study of Greek Architecture, Brill, pp.56-73, 2020, Monumenta Graeca et Romana 25, 978-90-04-41663-5. 10.1163/9789004416659_005. halshs-03409836

\section{HAL Id: halshs-03409836 \\ https://shs.hal.science/halshs-03409836}

Submitted on 30 Oct 2021

HAL is a multi-disciplinary open access archive for the deposit and dissemination of scientific research documents, whether they are published or not. The documents may come from teaching and research institutions in France or abroad, or from public or private research centers.
L'archive ouverte pluridisciplinaire $\mathbf{H A L}$, est destinée au dépôt et à la diffusion de documents scientifiques de niveau recherche, publiés ou non, émanant des établissements d'enseignement et de recherche français ou étrangers, des laboratoires publics ou privés.

\section{(1) (1) $\$$}

Distributed under a Creative Commons Attribution - NonCommercial - NoDerivatives $\mid 4.0$ 


\title{
New Directions and Paradigms for the Study of Greek Architecture
}

Interdisciplinary Dialogues in the Field

\author{
Edited by \\ Philip Sapirstein PhD \\ University of Toronto \\ David Scahill PhD \\ American School of Classical Studies at Athens
}

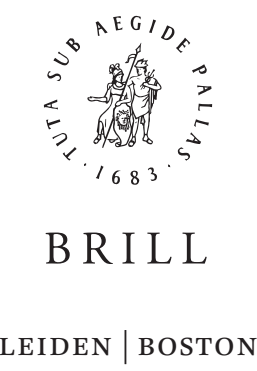

For use by the Author only | (C) 2020 Koninklijke Brill NV 


\section{Contents}

Preface IX

List of Figures and Tables XI

Notes on Bibliographic Abbreviations XVII

Notes on the Contributors XVIII

Introduction: Recent Developments in the Study of Greek

Architecture 1

Philip Sapirstein

PART 1

Planning, Organization, and Methods of Ancient Greek Architects and Masons

1 The Parthenon's North Colonnade: Comments on Its

Construction 21

Lena Lambrinou

2 New Evidence for the Construction Phases of the Parthenon Peristyle:

Anomalies at the Southwest Corner 39

Vasileia Manidaki

3 Ancient Blueprints: New Prospects and Interpretations in Light of

Recent Discoveries 56

Jeanne Capelle

4 Three Hellenistic 'Naïskoi' in the Theatre Area at Aigeira: Small

Buildings in the Context of an Urban Sanctuary 74

Alexandra Tanner

PART 2

Life History of Greek Monuments and Sites

5 The Small Limestone Buildings on the Akropolis of Athenai 91 Nancy L. Klein

6 Early Temples Built of Wood and Stone: New Finds from Kalapódhi (Phokis) 106

Nils Hellner

7 Recent Architectural Studies at Goúrnia in East Krete: 2011-2016 123

D. Matthew Buell, John C. McEnroe, Jorge Andreas Botero

Besadalombana, and Rafat Bieńkowski 
8 The Temple and Hestiatorion of the Sanctuary on Dhespótiko:

Archaeology, Architecture, and Restoration 135

Yannos Kourayos, Kornilia Daifa, Goulielmos Orestidis, Dimitrios

Egglezos, Vasilis Papavasileiou, and Eleni-Eva Toumbakari

\section{PART 3}

Architecture, Cultural History, and Communication

9 Building Change: Domestic Architecture and Identity during the

Bronze Age to Iron Age Transition $\quad 151$

Kyle A. Jazwa

10 Greek Temple Building from an Economic Perspective: Case Studies from the Western Peloponnesos 168 András Patay-Horváth

11 Old Questions and New Approaches: The Significance of Affinities between the Tectonic Arts and the Technical Arts of Ancient

Greece 178 Mark Wilson Jones

12 More than War: Symbolic Functions of Greek Fortifications 199 Silke Müth

13 Upcycling as a New Methodological Approach to Reuse in Greek Architecture 215

Sarah A. Rous

14 Looking at the Unfinished: Roughed-Out Ornamentation in Greek Architecture 229

Matthias Grawehr

PART 4

Simulation, Experience, and Interaction with Greek Architecture

15 Contexts for Greek Architecture: Places and People 243 Mary B. Hollinshead

16 The House of the Rhyta at Pseira: 3D Crowdsourcing in an Online Virtual Environment $\quad 258$

Miriam G. Clinton with Ansel MacLaughlin 
17 Comparing Greek 'Bouleuteria' and Roman 'Curiae': Two Case Studies on the Parallels and Differences in the Acoustic Reconstruction and Simulation of Roman Senate Sessions and Greek Boule Meetings $\quad 274$ Christian Fron, Verena Stappmanns, Xiaoru Zhou, and Philip Leistner

18 New Architectural Work on the Akropolis of Selinous, Sicily: Towards a Digital Platform for Cultural Heritage $\quad 289$ Clemente Marconi, David Scahill, and Massimo Limoncelli

19 Architectural Documentation and Visual Evocation: Choices, Iterations, and Virtual Representation in the Sanctuary of the Great Gods on Samothrake 305 Bonna D. Wescoat Index 323 


\title{
Ancient Blueprints: New Prospects and Interpretations in Light of Recent Discoveries
}

\author{
Jeanne Capelle
}

1

\section{Introduction}

The use of blueprints in construction yards is a key to our understanding of Greek architecture. ${ }^{1}$ It allows us to dispel misconceptions of the building process. The French mathematician Javary epitomizes such prejudices when he wrote in 1894 his question about the origin of "blueprints" ("épures" in French) in the mathematical journal l'Intermédiaire des Mathématiciens:

When can we say that we began to make blueprints, that is to say, geometric drawings that one tries to make as precise as possible? It seems that the Greeks did not create any blueprints; besides, it would have been very difficult for them; and their geometry, which was handled in a highly speculative manner, did not lead them in that direction. They must have drawn figures in the sand, on tablets, etc. to guide their reasoning and set down their ideas, but those were not blueprints.

According to scholars who have studied these questions, M. Choisy for instance, they did not make any blueprint even to raise buildings; at least their strict methods of calculation seem to aim at

1 This article was made possible through the permission and hospitality of the Turkish Ministry of Culture and Tourism as well as of the Greek Ephor of Antiquities Stavroula Sdrolia and the archaeologist Athanasios Tziafalias. I benefited from the generous support of Lyon 2 University (IRAA, HiSoMA, ED 483). I owe special thanks to the directors of the Miletos Archaeological Project, Christof Berns (Bochum University) and Philipp Niewöhner (DAI) for their encouragement throughout my investigations of the blueprints as well as to Alexander Herda for his guidance at the beginning of my research in 2014. I am grateful to Axel Filges (Frankfurt University) and Hakan I. Mert who kindly organized our stay at Priene and to Wolf Koenigs for his precious advice. I would also like to thank Richard Bouchon and Bruno Helly (Lyon 2) for their warm welcome at Larisa. I am greatly indebted to my husband, Ivan Boyer, who joined me to document the blueprints in 2015 and 2016. Lastly, I would like to express my gratitude to the editors of this book, Philip Sapirstein and David Scahill, for having organized such a stimulating event. Figures and translations are my own unless otherwise noted. More colour pictures are available on the videocast of this conference (http://www .ascsa.edu.gr/index.php/News/newsDetails/videocast-ancient-blue prints-in-light-of-recent-discoveries-the-theater-at). avoiding the necessity for blueprints (see M. Auguste Choisy's studies in Greek architecture: the Arsenal of Piraeus, the Erechtheion, etc.)

Who can be said to be the first one to have cared about the accuracy of a geometric figure? Or at least when did people begin to care about it?

JAVARY 1894

This conviction that blueprints cannot have been used in Greek architecture could already have been refuted and would be denied by the four responses to Javary's question in several issues of the same journal. In reality, Egyptian blueprints were known since the French campaign of Egypt (Jomard et al. 1821: vol. 4, 294-297, pl. 62, figs. 3-5). Tannery (1894) objects to Javary that blueprints should have been necessary for sundials, and Bouriant (1895; 1896) quoted some Egyptian examples used for stonecutting. Choisy (1894) claimed that blueprints were necessary for carpentry, as opposed to masonry, but he changed his mind when he published two Egyptian blueprints from Edfu (Choisy 1904), a couple of years after Borchardt's first synthesis on the subject (Borchardt 1896).

Still, Javary's mindset must be put into context: he wrote at a time when almost nothing was known about ancient blueprints, although technical drawings promoted by descriptive geometry were still widely used for stone-cutting, and also when mathematics could at last give an answer to ancient theoretical problems like squaring the circle, trisecting the angle, or duplicating the cube. Javary could not believe in ancient blueprints because of his idealistic vision of antiquity, of ancient geometry as speculative and abstract, and of ancient architecture as highly conceptual and fully predictable.

The example of Javary reminds us of the danger of retaining paradigms disconnected from reality. In this paper, a comprehensive answer to his question will be developed based on up-to-date evidence, looking not only for the origin of blueprints but also questioning what the geometry used in blueprints teaches us about Greek architecture and its design. First, what we may call ancient blueprints will be defined. Then a method for finding and studying them will be proposed. Last, an interpretation of such drawings will be attempted. 
2

\section{Ancient Blueprints: A Recent Research Field}

The word blueprint has already been used by Lothar Haselberger to refer to the famous construction drawings he discovered at Didyma and Rome in the 1980 and $1990 \mathrm{~s}$ (esp. Haselberger 1980; 1983; 1994; 1996). This modern name was a colourful way to address readers of Scientific American (Haselberger 1995). Since then I published a general, extensively referenced inventory of drawings (Capelle 2017a), and the current chapter provides a more global approach to the phenomenon. The word blueprint may refer to a "design plan or other technical drawing" in an architectural context. First used in the late 19th century, blueprint was derived "from the original process in which prints were composed of white lines on a blue ground" (adapted from the Oxford Dictionary of English 2016), i.e., the technique of cyanotypia: denoting first the multipliable copy of the architect's original plan, it came to mean the plan itself.

This describes perfectly the ancient findings in which lines appear white on a coloured ground or in few cases the reverse. Indeed, various techniques were used: at the Apollon Temple in Didyma, Haselberger found traces of a red chalk solution used to colour the wall before incising the lines - the blueprint that remains is a faint negative of this process (Didyma: Haselberger 1983: 92 [Didyma]; 1986 [reconstructing the process]). Wolf Koenigs (2015) argues that, in the absence of earth or mineral pigments, more transient vegetal ones (chlorophyll) might have been rubbed over the walls before drawing began at the Athena Temple in Priene, as was done in the 1960s at the Cologne cathedral (mentioned in Haselberger 1983: 92 n. 4). At Ephesos conversely, on the back wall of the Basilike Stoa in the Upper Agora, one can still see a thin layer of painting into which the lines (once studied by Wilhelm Alzinger but still unpublished) had been incised (Fig. 3.1). Blueprints could also be etched on thick mortar (Krause 1985 [Terracina, ca. 50 BCE]; Hanoune 1996 [Bulla Regia, after the second century CE; n. 9: Domus Augustea]) or simply painted on white stone, as in Hellenistic tombs of Makedonia (Hoepfner1984[Angista]) andThrakia(Čičikova, Stoyanova \& Stoyanov 2012 [Sveshtari]; Manetta, Stoyanova \& Luglio 2016 [Ostrusha]) as well as in the Egyptian quarries of $\mathrm{Abu}$ Fodah (Jomard et al. 1821; Petrie 1888).

In this article and line of research, we will use blueprint as a concept referring to a specific kind of architectural drawing that is always made on monumental architecture, mostly on marble, on a flat surface, either vertical or horizontal, that is, on walls or on paving. Some drawings were made on limestone-not surprisingly on marmoreal, crystalline limestone at the Ptolemaion of Limyra (Stanzl 1999) or the sanctuary of Mars Mullo at Allonnes

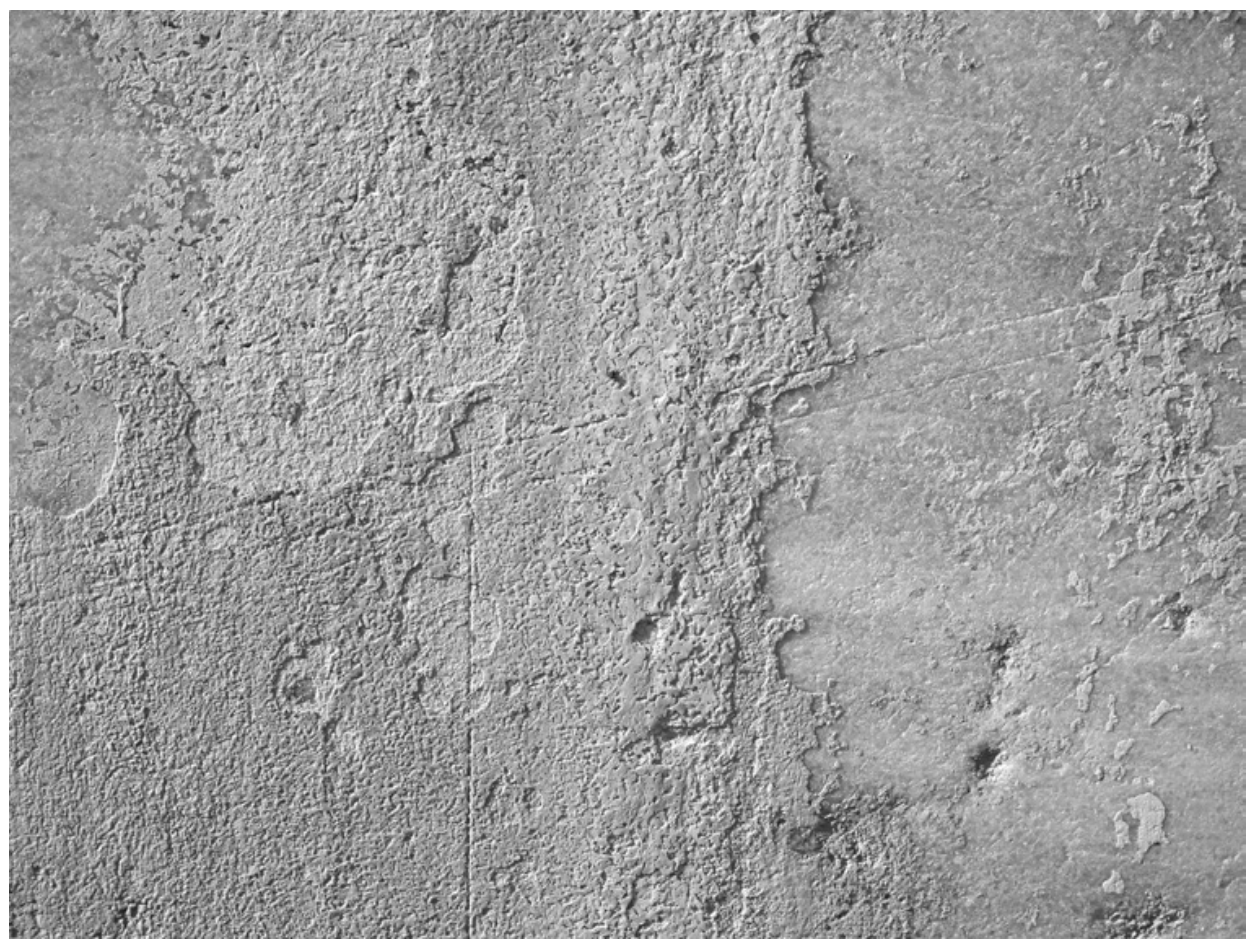

FIGURE 3.1 Ephesos, Upper agora, basilike stoa, vertical and oblique lines incised in a coat of paint. The "blueprint" is visible on the surface of the marble AUTHOR 


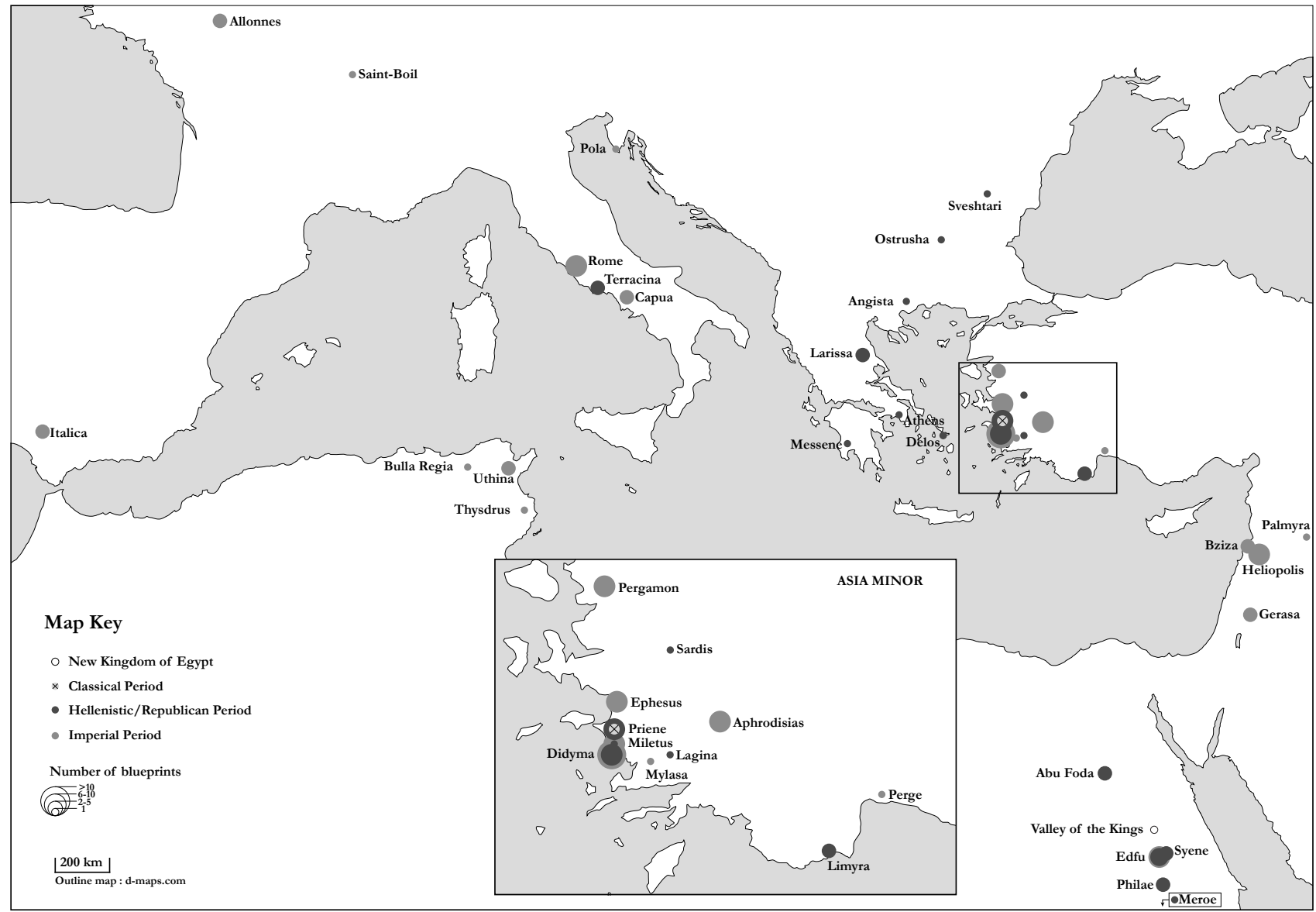

FIGURE 3.2 Chronological map of blueprints AUTHOR

in France (Brouquier-Reddé \& Gruel 2003), but also in the quarries of Abu Fodah (see above) or on travertine at the Amphitheatre of Capua (De Franciscis 1983) and at the Mausoleum of Augustus (Haselberger 1994; 1996) sandstone at Philai (Borchardt 1896) or on plaster, as stated above. This kind of drawing represents architectural elements or details - never a whole building (a partial exception is the drawing delineating the general shape of a small Meroitic pyramid; see Hinkel 1976; 1980; 1981) in elevation, plan or section. It differs from setting lines in that it is made on an independent surface selected for drawing. It plays a role in the construction of the building on which it is made-or rarely a nearby one; some monumental exceptions include the blueprints for the Pantheon and possibly other buildings at the Mausoleum of Augustus (see above; Capelle forthcoming) and according to one interpretation a blueprint for the Temple of Artemis inside the Temple of Apollon at Didyma (Weber et al. 2015; Weber 2015). It is carefully realised with drawing tools (sharp drawing point, compass, ruler, set square) to scale, in most cases at a 1:1 scale; only about $20 \%$ of the cases are at reduced scale. Incision is the most common technique, but it is not necessary (see above). This definition excludes setting lines; marks for clamps; axes and guiding lines for stonecutting; preparatory lines for the carving of mouldings; and architectural graffiti which share common features with blueprints but should be distinguished from them.

We know today of over 120 drawings meeting this definition from which we can suggest the following chronology shown in Figure 3.2.

Although it is hard to give a definite answer to Javary's question about the origin of blueprints, one may argue that it is definitely not a Greek one. Indeed, among the many ancient Egyptian models and architectural drawings, most of which are reduced plans drawn on small, movable material, there is one that can be considered a blueprint. It dates to the New Kingdom of Egypt - more precisely to the second half of the 12th century BCE - and represents in elevation the elliptic vault of the chamber of the tomb of Ramses vi at the Valley of the Kings, painted at full scale in the passageway of this tomb; the masons who carved the chamber probably took measurements from it (Daressy 1907, with figure). Nevertheless, this case is isolated.

If we come back to Greek architecture, there is a noticeable gap during the Archaic period: we know plenty 


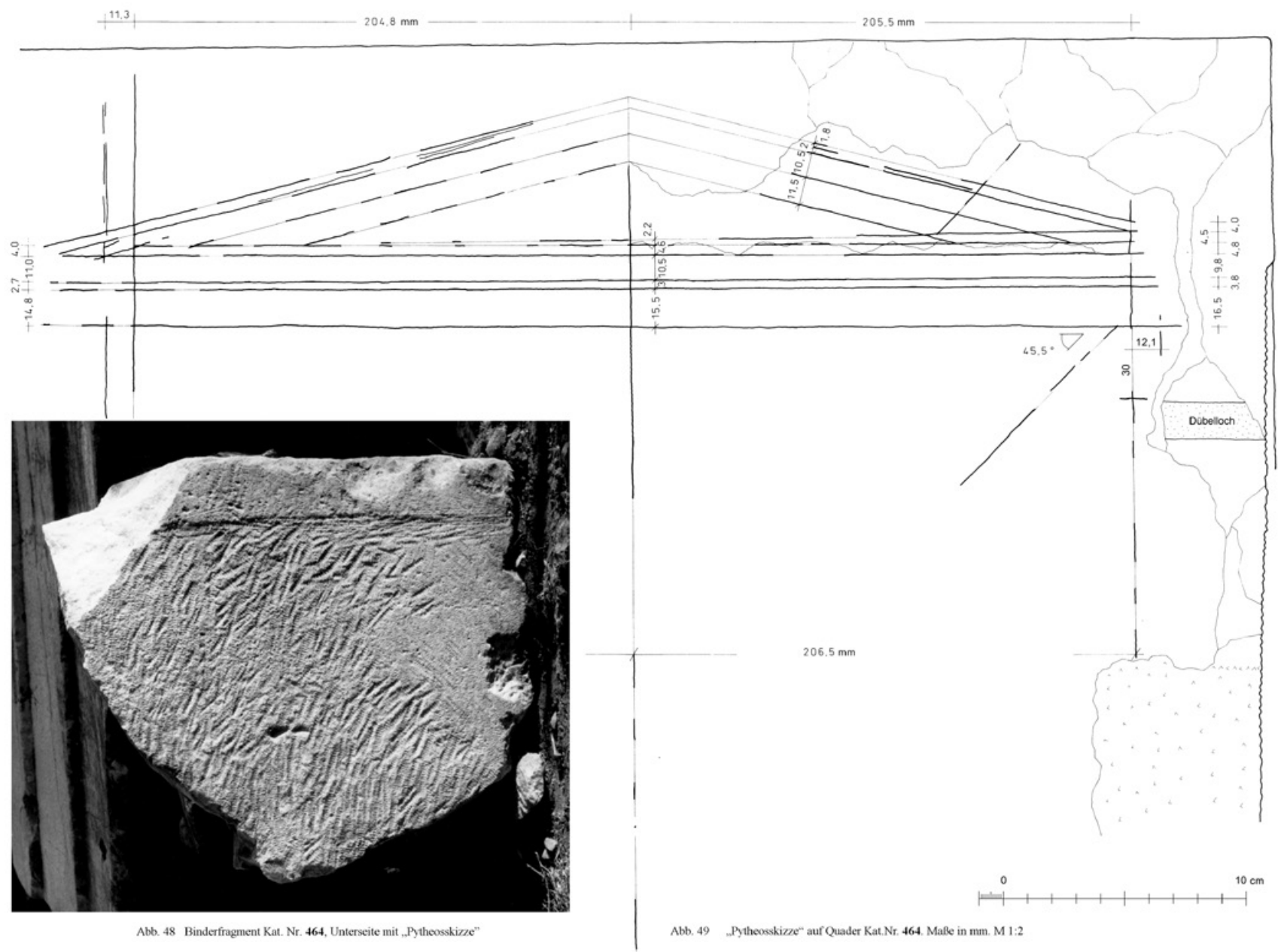

FIgure 3.3 The "sketch of Pytheos" at the Athena Temple of Priene, ca. 340 BC COURTESY W. KOENIGS

of setting lines to guide the construction of buildings by delineating their plan on the top of the successive courses, but none of these drawings can be considered a proper blueprint (Petronotis 1968; 1972). One of the drawings at the Old Temple of Aphaia on Aigina has been compared to a blueprint by Ernst-Ludwig Schwandner (1985: 80), but it corresponds to a reused stylobate block with setting lines for a column. As observed by Clemente Marconi (pers. comm.), the absence of evidence for the Archaic period might be explained by an insufficient preservation of the monuments. Likewise, my distribution map (Fig. 3.2) is but an incomplete picture of what was most certainly a widespread phenomenon. The only blueprint that can be dated to classical times is the so-called "sketch of Pytheos" at the temple of Athena at Priene. It represents an elevation of the entablature and the pediment of the naos (Fig. 3.3) and dates to the second half of the fourth century $\mathrm{BCE}$, at the start of the Hellenistic period (Koenigs 2015: vol. 33, no. 464).

Blueprints indeed develop during this period, possibly because of the greater variety of buildings and architectural forms which required more than setting lines. From this time onward, elevations, plans, and sections are employed, sometimes combined for complex objects like columns or capitals, and most at full scalerepresenting a marked change for the working out of design directly in the field. Blueprints continued to multiply all over the Mediterranean during the Imperial period.

In fact, the practice never really ceased from the Middle Ages to the present day, as many European cathedrals show (e.g.: Inglese 2014; Sakarovitch 1998; and Ruiz de la Rosa 1987). A recent, rarely cited case is that of the so-called "masons' room" of the castle of Blois in France. During the restoration of the castle from the 188 os to the 1920s, the walls of this room were covered with blueprints (Fig. 3.4). Although these drawings serve a slightly different purpose since they are about rebuilding, not building, they share common features with ancient blueprints, like the superimposition of drawings; the similarity of some of the objects represented (arch, entablature, pediment); the presence of a volute from nearby Saint Vincent's next to a pediment from the castle; and the many frontal views and 


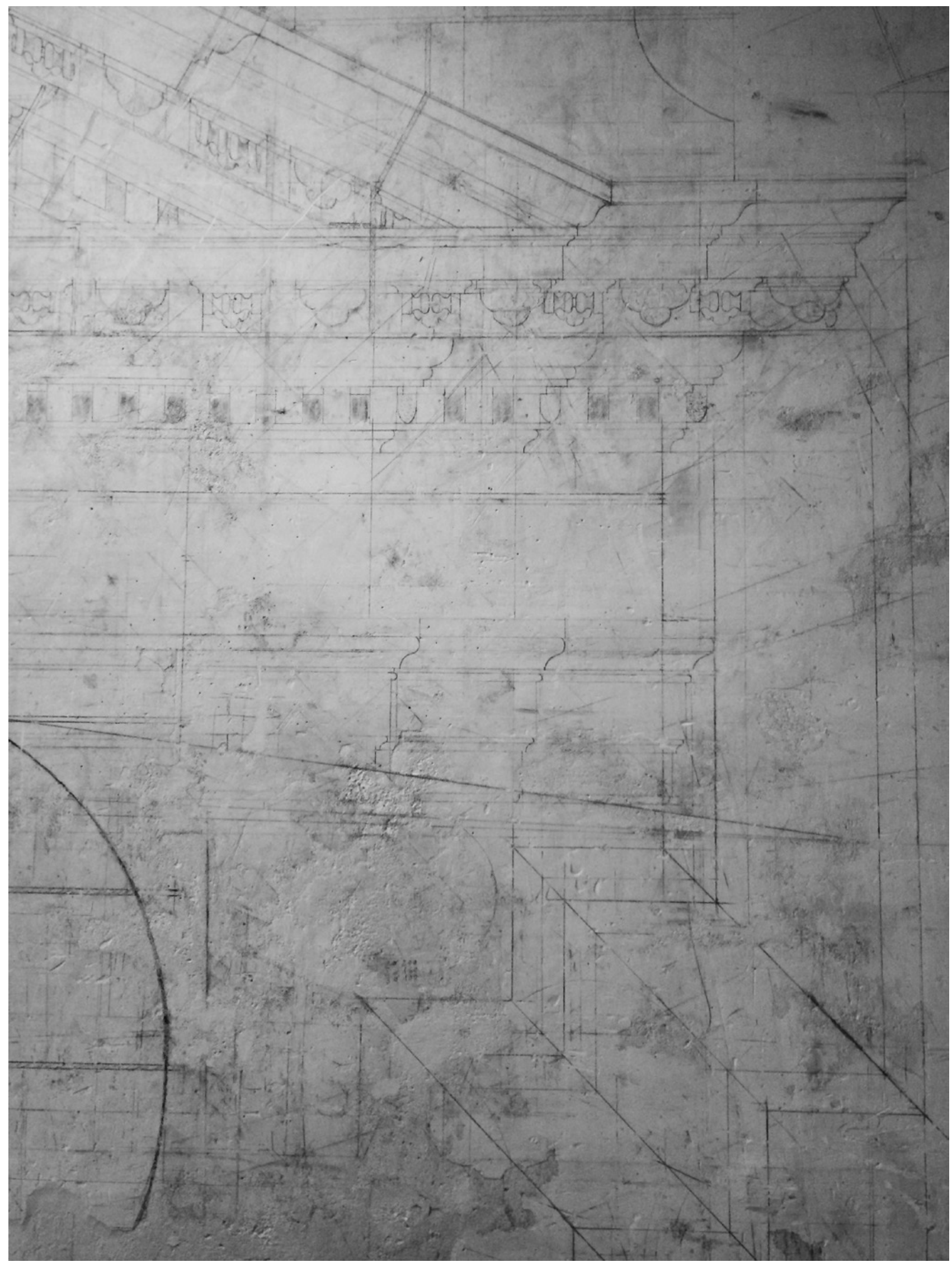

FIGURE 3.4 Blueprints from the "Mason's room" at the Castle of Blois, France, incised in the mortar or drawn on it with charcoal or red chalk during the restoration of the 1880 s- 1920 s AUTHOR 
moulding profiles, whereas a few axonometric views contrast with the ancient drawings. We may also remark that the drawings are on a thick layer of mortar; the technique varies, combining incisions, charcoal, and red chalk; and the quality fluctuates. Lastly, there are also numbers, diameter indications, computations, notes, graffiti, hatches, and the like. Without being anachronistic, if we consider the richness of this well-preserved evidence, we may wonder if there was not much more to the ancient drawings than the scanty lines which have partially survived.

\section{$3 \quad$ Methods for Finding and Recording Blueprints}

We may argue that the few drawings we know today are but rare survivals of a widespread phenomenon. It is important to develop a method to look for hitherto unknown blueprints and decipher them. Since blueprints are difficult to see, the first problem is determining the right place to look for them. The type of building (Fig. 3.5) is not much help: about half of the blueprints are in temples, on the inner or outside walls of the cella, but they are not uncommon in many other public buildings as well as in monumental tombs and quarries. Theatres are well represented: at Bulla Regia (Hanoune 1996), possibly Terracina (Krause 1985), Perge (to be published by Frank Rumscheid), Aphrodisias (Hueber 1998; Capelle 2017a), Miletos (Capelle 2017a), Priene, and Larisa (below, part 3). Of course, the ratios shown in the figure may change with new discoveries in other buildings.

If we consider now the location of blueprints inside the buildings, the example of the theatre at Miletos shows that they can be situated both in a closed space-as the hyposkenion under the stage - as well as in an open onelike the western retaining wall (below, Fig. 3.8b). It is clear that the latter was drawn as close as possible to the object, rendering the arches constructed higher up on the same wall; in the hyposkenion, one pediment of the first Imperial scaenae frons is drawn on its very foundations, along with the base of the nearby terminal pedestals of the retaining walls (Fig. 3.6a). Other drawings which will be discussed below in section 3 are in a similar position: at the Bouleuterion of Miletos (Fig. 3.6c) a blueprint for the seats is located inside the corridor before the auditorium,

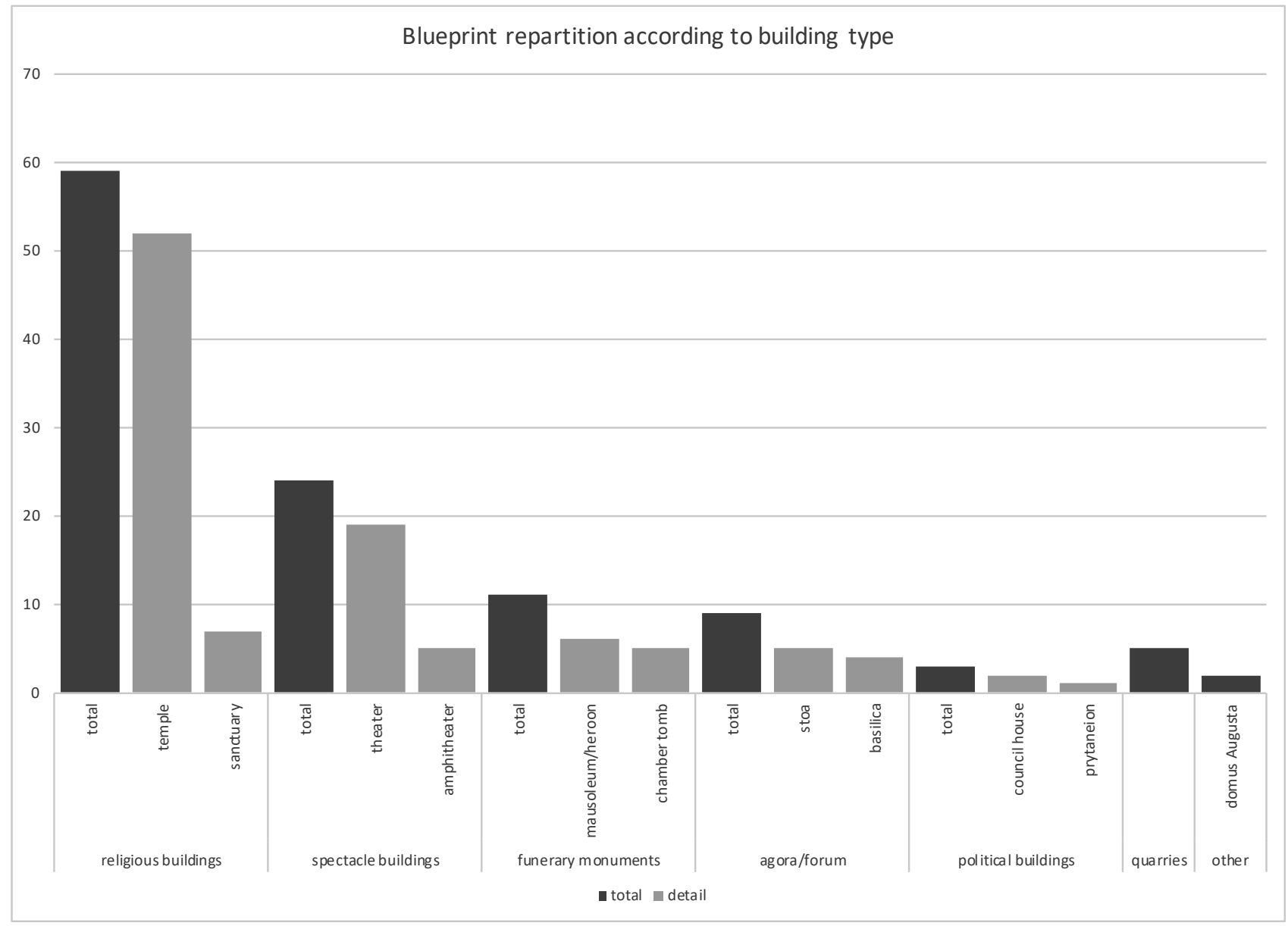

FIGURE 3.5 Known blueprints quantified according to building type AUTHOR 

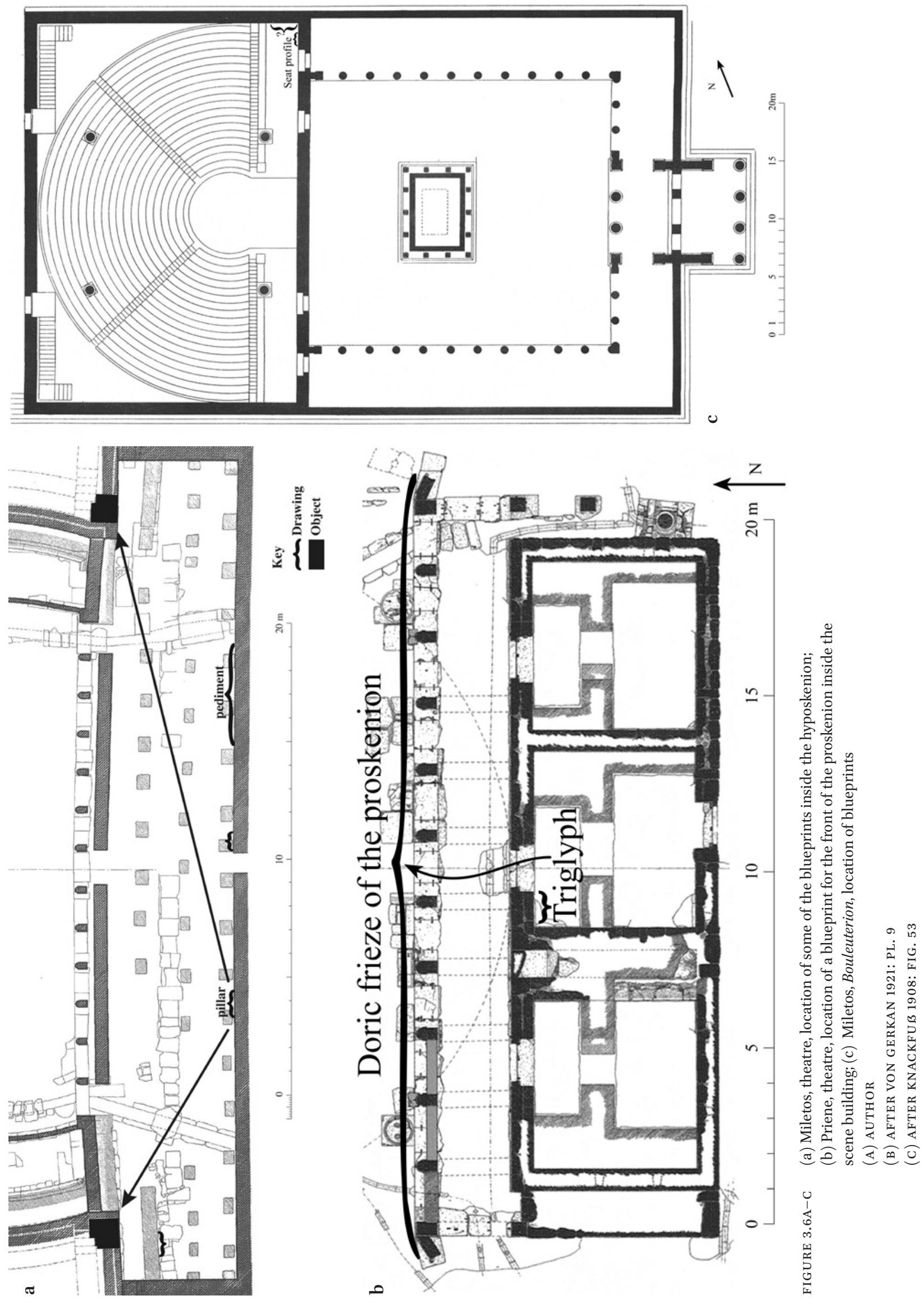

For use by the Author only | (C) 2020 Koninklijke Brill NV 

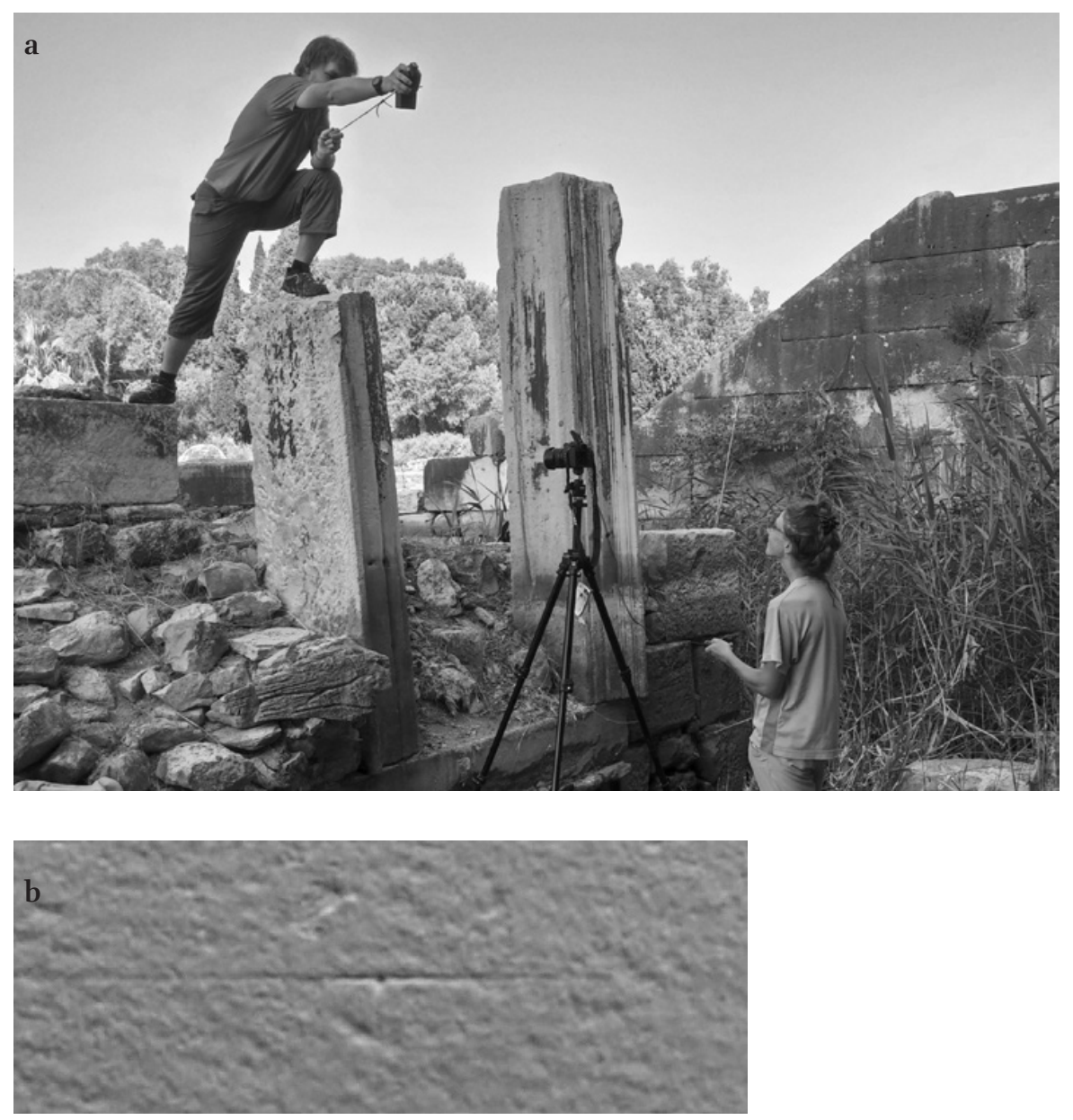

FIGURE 3.7 (a) Using RTI with I. Boyer at Miletos, here on a Christian monogram. (b) Specular enhancement, snapshot from RTI-Viewer of a horizontal line with a compass hole in its middle
(A) COURTESY A. VACEK
(B) AUTHOR

and at the theatre of Priene (Fig. 3.6b) the Doric frieze of the proskenion is drawn in the middle room of the skene.

It appears that blueprints may be found in any monumental building next to their subject. There are special spots one can examine closely: a blueprint requires a smooth, easily accessible, and large surface. All these requirements are met by orthostates, which are particularly tall and set at eye level, and indeed a vast majority of blueprints or at least their lower lines are drawn on orthostates. For instance, the western retaining wall of the theatre at Miletos-including its profile (Krauss 1974) - is quite similar to the inner walls of the temple at Didyma where Haselberger found so many blueprints.

Once a blueprint has been identified, however, deciphering it is still a difficult matter. Most frequently, one looks at weathered surfaces and needs to be in the right place at the right time. Oblique light from the sun or light reflected by a mirror helps to reveal the lines. However, it is often impossible to have a full view of the drawing because many lines can only be seen from extremely close up. Some basic principles may help to see more. By putting one's eye at the end of a line, one can see that it continues farther than when one looks at it frontally. A piece of string can help us find compass holes, but also the continuation of lines and curves which have partially vanished. It has proved helpful as well to have a comprehensive view of the six lines of the pediment drawing and their two different slopes from Miletos, as will be discussed in the following section (below, Fig. 3.8a).

Regarding documentation, a squeeze worked for the extremely well-preserved, deeply carved "Pytheos sketch" at Priene (Koenigs 2015: fig. 48). But in Miletos, as in many places, the surface of the blocks is not smooth enough since it is picked, and the lines are too worn to feel their depth. For this reason we applied Reflectance Transformation Imaging (RTI) to the blueprints of Miletos (Fig. 3.7a). This technique, developed at the beginning of the 2000 s by Tom Malzbender at Hewlett-Packard Labs, 


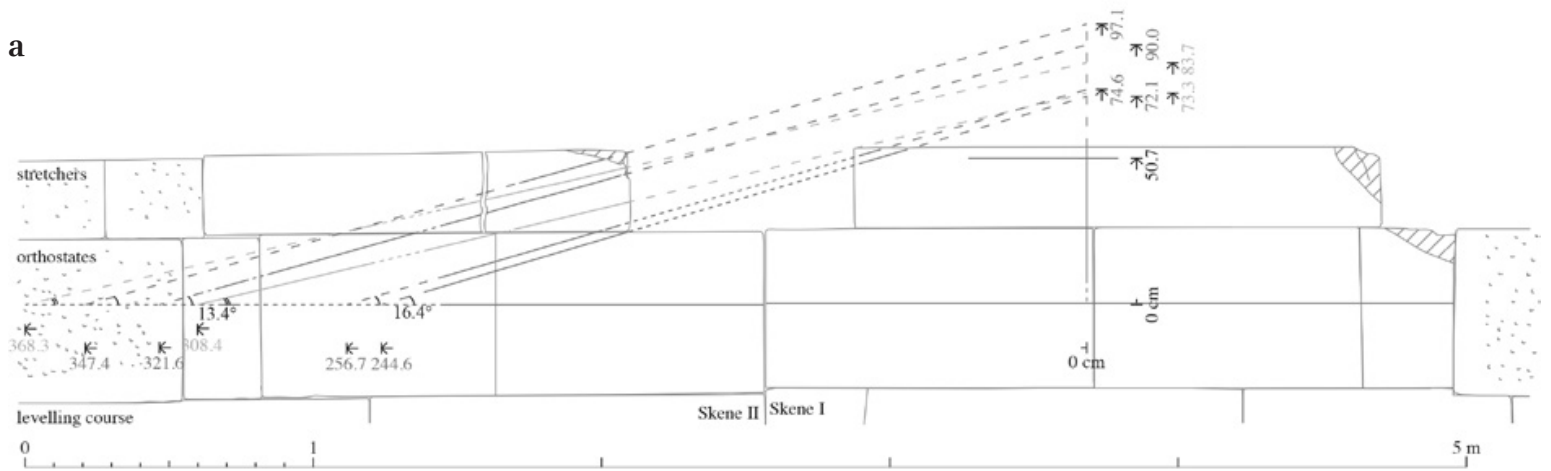

b

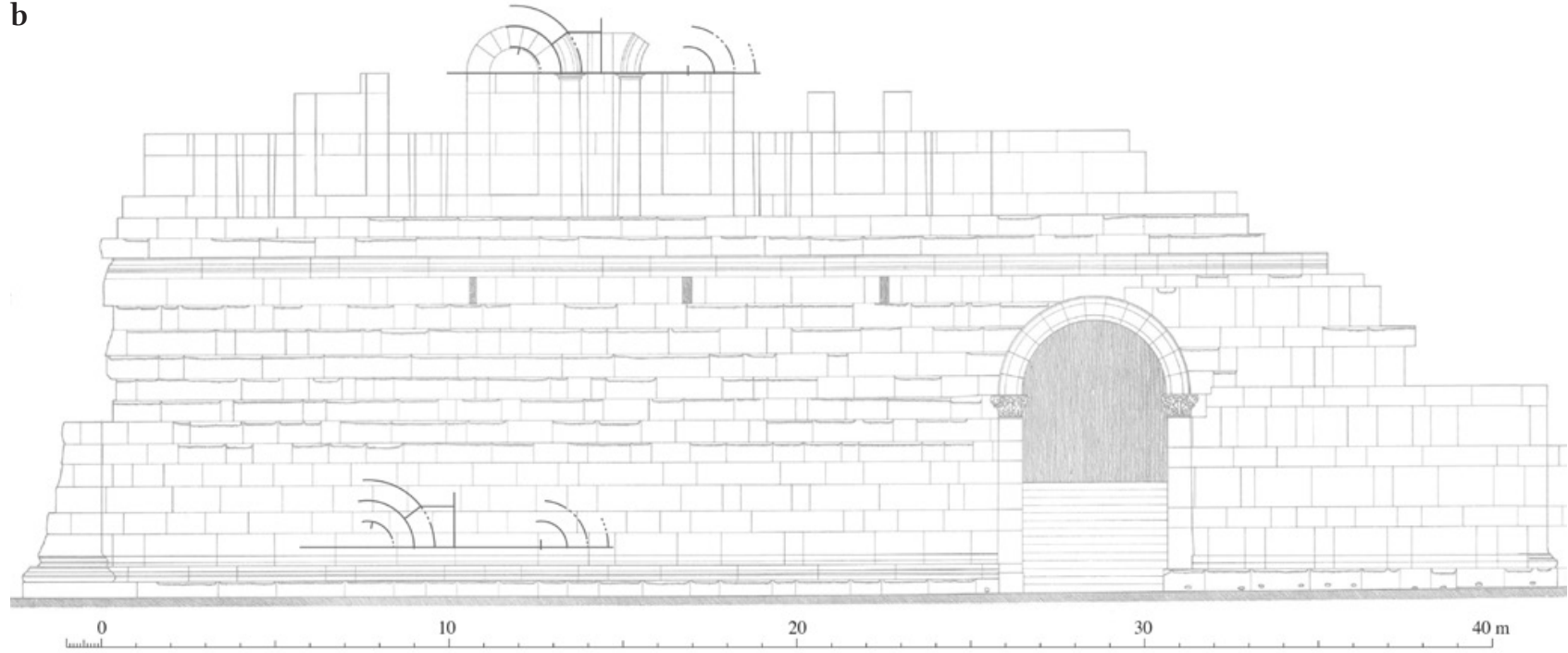

FIGURE 3.8 Miletos, theatre: (a) blueprint of a pediment of the first Imperial scaenae frons; (b) blueprint of the arches of the western retaining wall

ADAPTED FROM KRAUSS 1973: PL. 18, KEEPING ONLY THE EXTANT REMAINS AS DRAWN BY KNACKFUß

enabled us to combine in the same image varying lighting conditions, which are produced by an autonomous flash placed at various angles. After having rendered the image with the RTI-builder software, one can visualise it with the RTI-viewer, using the specular enhancement (Fig. 3.7b) and changing the light as much as one likes. The "normals visualisation" offers an equivalent of a virtual squeeze which helps us to ensure that the visible lines have some depth.

RTI proved to be able to reveal barely visible inscriptions (Capelle 2017b), especially those marking reserved seats ("topos inscriptions") in the theatre, but the results are less spectacular for blueprints: we used it mostly to ensure that the lines we discerned with the naked eye and good lighting had a real depth, though we occasionally also found some new markings. Nevertheless, RTI can be considered the most commonly adapted technology for these kinds of meticulous studies: it is particularly suited for deciphering hardly visible fine surface deformations and superimposed incisions. ${ }^{2}$

2 In comparison, $3 \mathrm{D}$ white light scanning and ${ }_{3} \mathrm{D}$ modelling has been attempted in Didyma: it took two nights and five days of data processing to obtain the same results as Haselberger with the naked eye for the "entasis drawing" (Bankel 2013). For a convincing application of both RTI and $3 \mathrm{D}$ (photogrammetry) as complementary technologies, the first one being useful for deciphering details, the second one for collecting data on a larger scale, see the El Morro Project (http://culturalheritageimaging.org/What_We_Do/Projects/elmorro/ index.html). Another significant advantage of RTI is that anyone can process the data efficiently using the free Hewlett-Packard software (http://culturalheritageimaging.org/Technologies/RTI/) and affordable equipment. 
The Uses of Blueprints: Between Theory and Practice

It is not an easy task to give an interpretation of the silent evidence we have of ancient blueprints. We cannot know for sure if they were drawn by architects, overseers of work teams, or stone masons. When one looks at, for instance, modern French treatises on architecture and stereotomy from the 18th century to present, the answer varies, but often mentioned is the special role of blueprint-maker assumed by the "appareilleur" — the "dresser" of stone or the "fitter" who puts the blocks together (from Jaubert \& Didot 1773, s.v. Appareilleur to Sakarovitch 1998: 11-12). The appareilleur is a key intermediary who works out how the stone will be cut by the stonemasons to execute the architect's design. This dialectic of theory and practice may guide us to a valid interpretation of some recently discovered ancient drawings.

The earliest identified drawing from the theatre of Miletos probably represents one of the small pediments of the scaneae frons of the first century CE (Fig. 3.8a) (Capelle 2017a). This is an important piece of evidence for the reconstruction of the first Imperial scaenae frons (Altenhöfer 1986), as very few blocks from the five pediments have survived. It seems clear that the drawing contributes to the design by comparing two different slopes, which has serious implications for the general shape and dimensions of the pediment. Even if a general idea existed, it was discussed and adapted in the field. Furthermore, once one choice was made, one could still add information to the drawing. Lines, perhaps added later on, that are parallel to the steeper of the two slopes provide additional measurements for the simas, and the drawing probably served as a reference for the masons as well.

If we consider the drawing of the arches of the western retaining wall (Fig. 3.8b), which dates to the second century $\mathrm{CE}$, the diagram is contemporary and measures exactly as the real arches - which were built without a change in decision. It may just be the geometric representation of a well-defined design, beginning with a 30 -foot-long horizontal line which is divided into parts. As for the pediment and most of the drawings, only half of the symmetrical shape is drawn, and it is protracted towards the left just enough to give the necessary lines for stonecutting: one of the springers with its special shape and the keystone to which the four other voussoirs are equal. We are at the last stage of design, just before execution. Nonetheless, the effort of drawing out the two arches would still have something to do with testing their proportions.
As a third example, we may examine two of the four detailed drawings which were designed in the hyposkenion at Miletos. We can find side by side the upper and lower profiles (Fig. 3.9a) of the terminal pedestals of the retaining walls, which date to the second century CE. The eastern one bore the statue of the Asiarch M. Antonios Apollodoros (Fig. 3.9b) (Krauss 1973: no. 936). The lower profile on the right once continued on the next course but is now lost. We can imagine that it was useful for the stonecutters to take measurements from the drawing and use some lines as references. One tangent of the base drawing corresponds to a roughed-out surface visible under the steps of the staircase (Fig. 3.9c).

Still, these drawings are much more than just profiles for masons to copy. They are the result of geometric constructions which define the respective proportions of the subdivisions of the moulding. In the lower left corner of the geison drawing, we can see a construction angle that corresponds to a 3:4 ratio. In all probability, it served to fit a set square whose perpendicular arms were set to this 3:4 proportion, so that the same ratio could be applied at least three times to divide the moulding into parts (Fig. 3.9d). This can be achieved by a typical Euklidian construction (Fig. 3.9e), which we could describe as follows:

Given two parallel lines, put a set square following the required proportion parallel to the lines. Carry the height forward onto the lowest horizontal. Then draw a vertical perpendicular to it and draw a new horizontal where it intersects with the slope of the square. You now have the desired proportion (after Euc. 6.2 Intercept theorem).

A last interesting feature of this drawing is that the general design is broken down into parts, and the profile has been shifted left, right, and up for the upper part, which follows a different proportion of 2:3 (Capelle 2017a: fig. 11). This blueprint indicates a very pragmatic application of the principles of Euklidian geometry to architecture. The geometric construction is part of the design and can be read as directions by the stonecutter.

Furthermore, it seems that even if a general idea of the design exists, the drawing could still be a place where the details and the inner proportions of a given shape were determined. A clear example of Hellenistic date can be found at the Milesian Bouleuterion. It represents the profile of the original seats of the auditorium, which were replaced in Imperial times (Fig. 3.10a) (Knackfuß 1908: 35, 


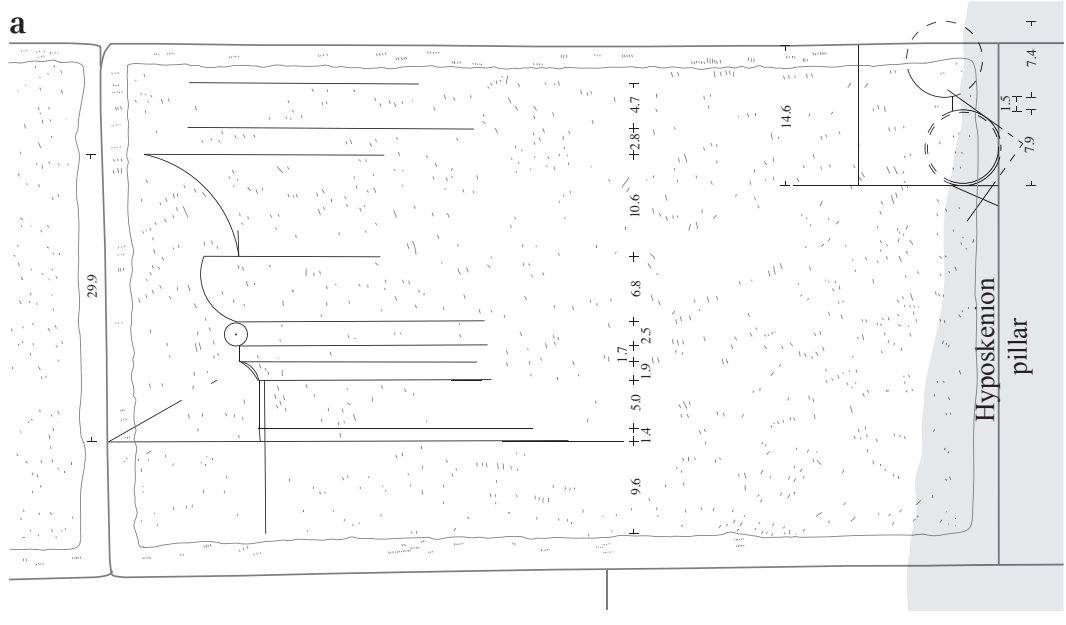

$0 \quad 10 \quad 100 \mathrm{~cm}$
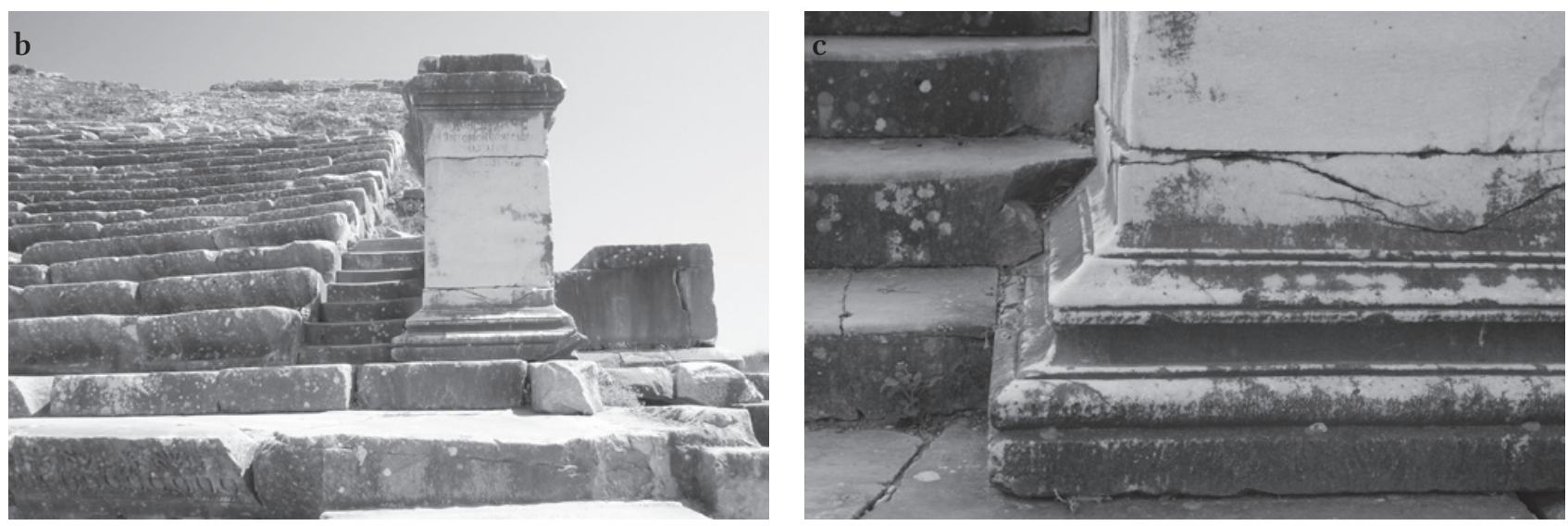

d

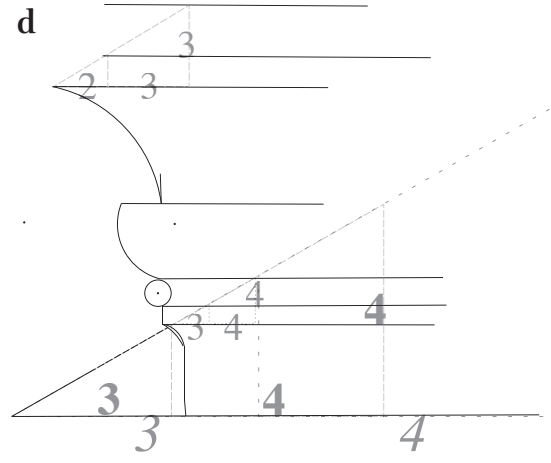

e

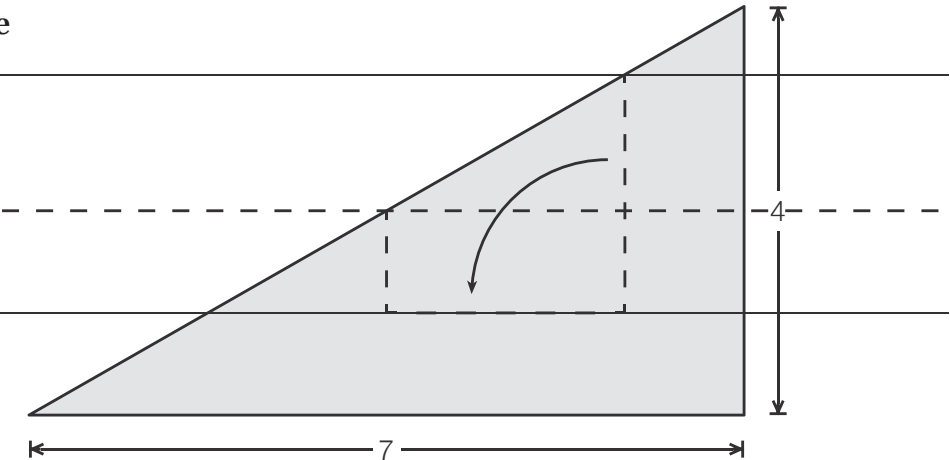

FIGURE 3.9A-E (a) Miletos, theatre, blueprint of the upper and lower profile of the terminal pedestals of the retaining walls; (b) ending pedestal of the eastern retaining wall, with the inscription of the Asiarch M. Antonios Apollodoros; (c) original roughing out surfaces preserved under the steps of the staircase; (d) proportions used in the drawing; (e) Euklidian construction with a proportion square AUTHOR 
fig. 8). As far as I know up to the present, the representation of seat mouldings on a blueprint is unique.

Somewhat surprisingly, the drawing is of a well-known profile used not only at the Bouleuterion, but also at the stadium and the theatre of Miletos (Fig. 3.10b). It can also be observed in Priene-in its Bouleuterion and in the lower proedria of the theatre (Fig. 3.10c) —and on Samos (Gerkan 1921a: 3, fig. 2 [stadium at Miletos]; 1921b: pl. 14 [theatre at Priene]; Krauss 1973: 79-89, pl. 27-28 [theatre at Miletos]; Wiegand \& Schrader 1904: 224, fig. 218 [Bouleuterion at Priene]; for Samos see the marble bench displayed today in the courtyard of the Pythagoreion museum). All dated examples go back to the beginning of the second century вСЕ, apart from the Imperial cavea of the theatre of Miletos, the lower part of which seems to be a reassembling of an older koilon (some clues not reviewed here suggest a reuse of the Hellenistic seats). We may wonder why such a canonical moulding was drawn with so much hesitation. Apparently, the shape required some adaptation. Each profile has its own variations, and it seems that the beginning of the ovolo was shifted down to find the desired ratio between the convex and concave parts of the moulding. One might even have used an existing template from another building, and tried to move the upper and lower lines to modify the shape.

As at the theatre, this blueprint was not isolated: another drawing (Fig. 3.10d) covers the two orthostates (the right one of which was not recovered in situ) of the northern wall of the corridor next to the other blueprint. Its identification remains uncertain but the intervals between the vertical lines seem to match the various widths of the lotus and palmettes which adorn the frieze of the raking sima of the auditorium (see Knackfuß 1908: 48-49, fig. 6, pl. 9-10).

Lastly, it is certain that blueprints were only one part in the chain of architectural drawings. At the theatre of Priene a drawing on the northern wall of the central room of the scene building probably works out the partition of the triglyph in the Doric frieze of the proskenion (Fig. 3.11a). The vertical axis equals the total height of the entablature, which is one third that of a column. The 3-mm discrepancy between these two intervals is not an obstacle to this interpretation. On the contrary, as observed by A. von Gerkan (1921b: 38) and J. Misiakiewicz (Schumacher \& Misiakiewicz 2007: 57-58), the whole scene building of Priene, including its triglyphs, is full of such irregularities which one does not notice at first sight. It may be the sign of a continued carelessness through the chain of drawings.

Indeed, the blueprint has similarities to other kinds of drawings, such as the delineation of the plan of metopes and triglyphs found on the floor of the Angista tomb by
W. Hoepfner (Fig. 3.11b) (Hoepfner 1984: 22; Katerina Charatzopoulou kindly informs me that she will reexamine the drawing in her chapter about the architecture and the ornamentation of the tomb in a forthcoming book under the direction of Chaido Koukouli-Chrysanthaki). Many setting marks in turn respond to that drawing, such as the lines (i.e., crosses) on the top surface of the epistyle blocks corresponding to the regulae at the Bouleuterion of Miletos. We can also find various marks which are reminiscent of our elevation drawing on the front face of frieze blocks in Delos. On one block of unknown origin at the Hypostyle Hall (Fig. 3.11c) (Poulsen \& Vallois 1914: no. 40), a line marks the vertical axis, whereas a horizontal line is drawn above the glyphs on the triglyph blocks from the late Hellenistic porticoes of the Agora of the Italians (Fig. 3.11d) (Lapalus 1939). So it seems that not only could the project materialise through a blueprint, but also the blueprint could help workers when they were carving guide marks before cutting the stone.

Finally, a recently discovered example summarizes many of the foregoing points while showing how one blueprint can clarify the interpretation of many others. In November 2017, we identified a blueprint incised on the western retaining wall of the theatre of Larisa, Thessalia, on smooth orthostates at eye level. If one looks casually, one can hardly see anything. But with some patience and some lengths of string, one may retrace long horizontal lines which are reminiscent of column drawings on the temple of Didyma and the theatre of Aphrodisias, which make clear that it is easier to rotate the elevation drawing horizontally (Fig. 3.12b) (Haselberger 1980: 193-202, fig. 1-3; Hueber 1998: fig. 9). A search for a column whose dimensions coincide with those of the diagram resulted in an exact match to the half-columns of the proskenion (Fig. 3.12a). There are even setting lines delimiting the lower diameter on the stylobate, the axis and the circumference of the column, and some additional marks for the flutes (Fig. 3.12c).

The circle in the middle of the drawing corresponds to the plan of the lower diameter, as with the superimposed drawings of section, elevation, and plan of the column at Didyma. But contrary to the entasis drawings of Didyma and Aphrodisias, we have at Larisa a study for the narrowing of the shaft. The working out of the design appears also with the two middle vertical lines, which delimit a Thessalian foot of ca. $31.9 \mathrm{~cm}$; this approximation seems to be confirmed by the $31.91 \mathrm{~m}$ long-most probably hekatompedon-retaining wall. The shaft follows a 1-1/4 by 7-1/2 ft. scheme for a proportion of 1:6. The drawing was close at hand for the builders. They may have also checked 


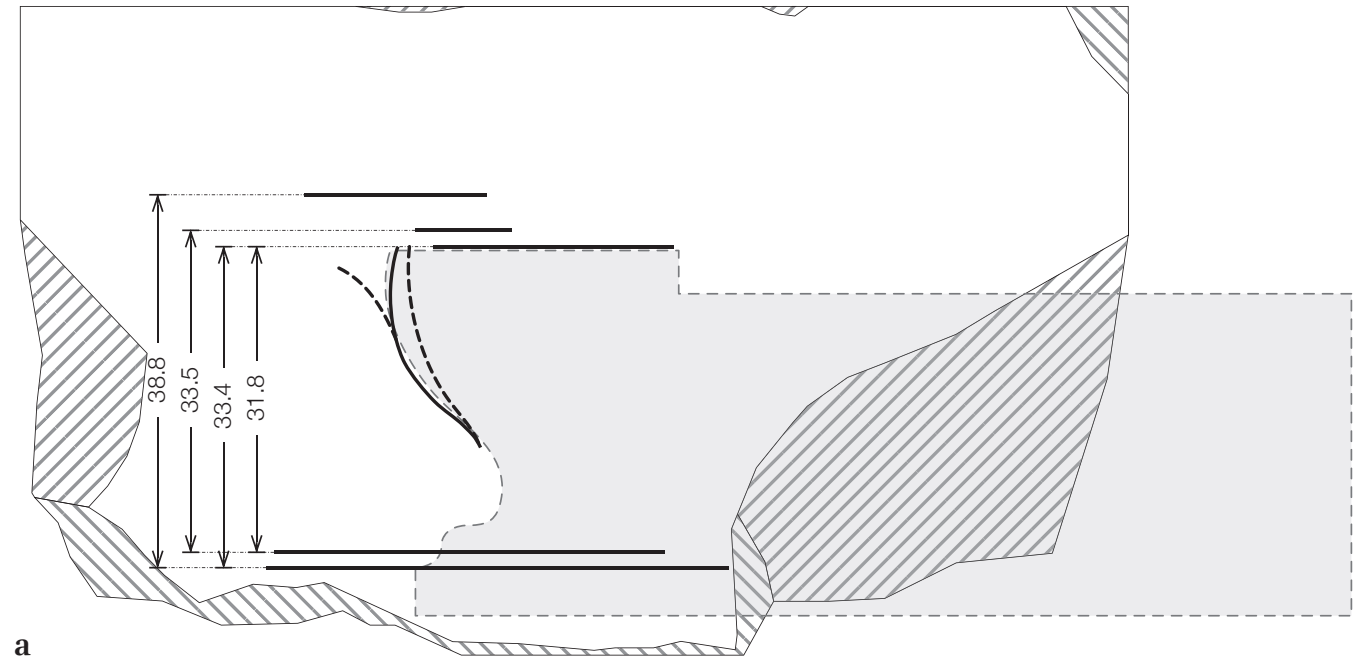

0510

50

$100 \mathrm{~cm}$

b

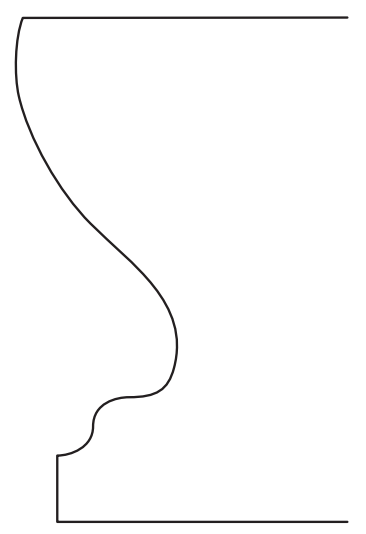

Council house

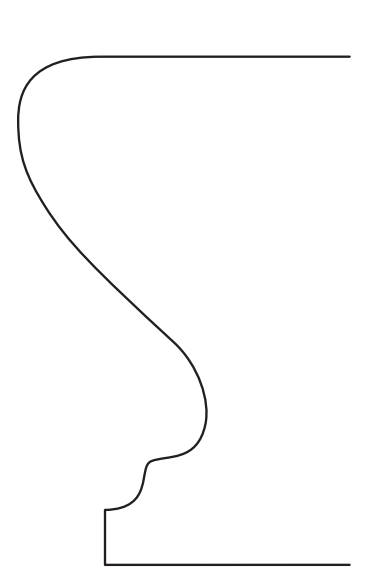

Stadium

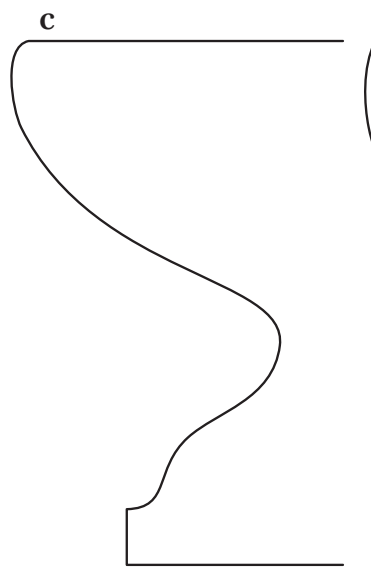

Theater, ima cavea
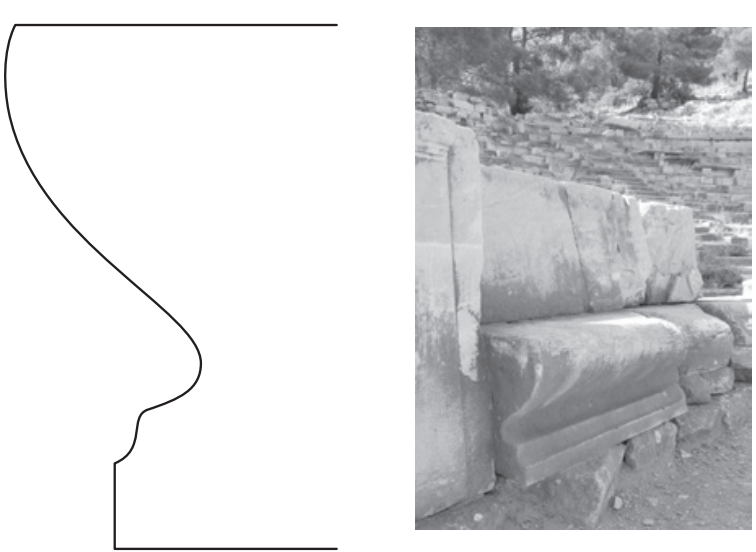

Theater, summa cavea

d

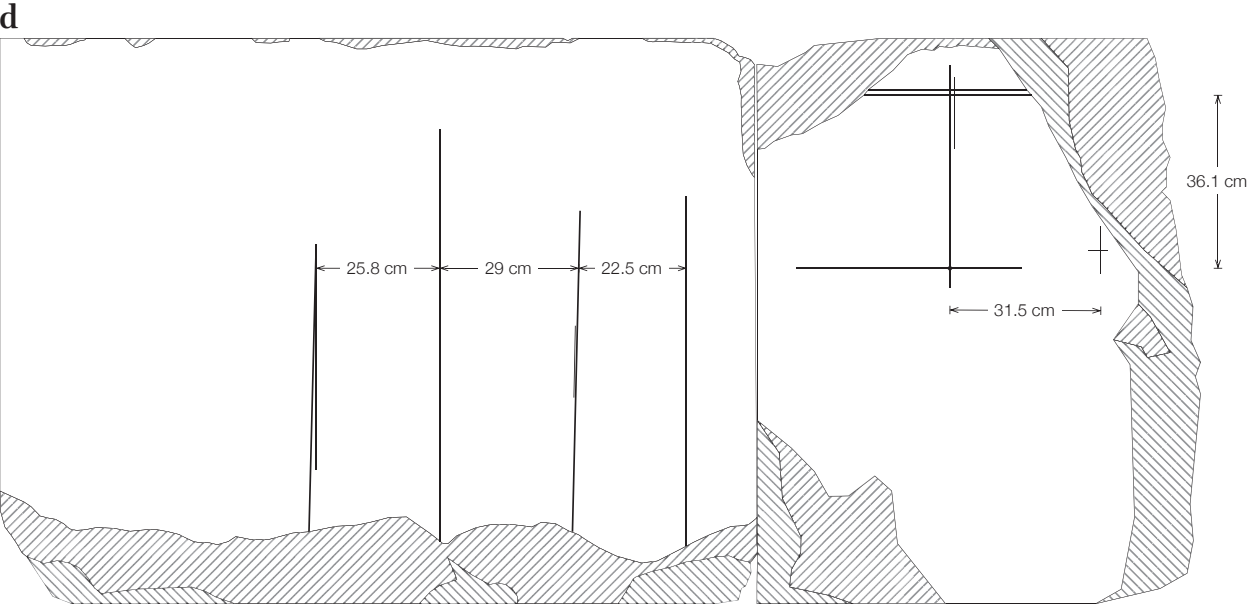

FIGURE 3.10A-D (a) Miletos, Bouleuterion, blueprint of the Hellenistic bench; (b) similar profiles at Miletos; (c) Priene, theatre, lower proedria; (d) Miletos, Bouleuterion, unidentified blueprint (frieze?) AUTHOR 
a

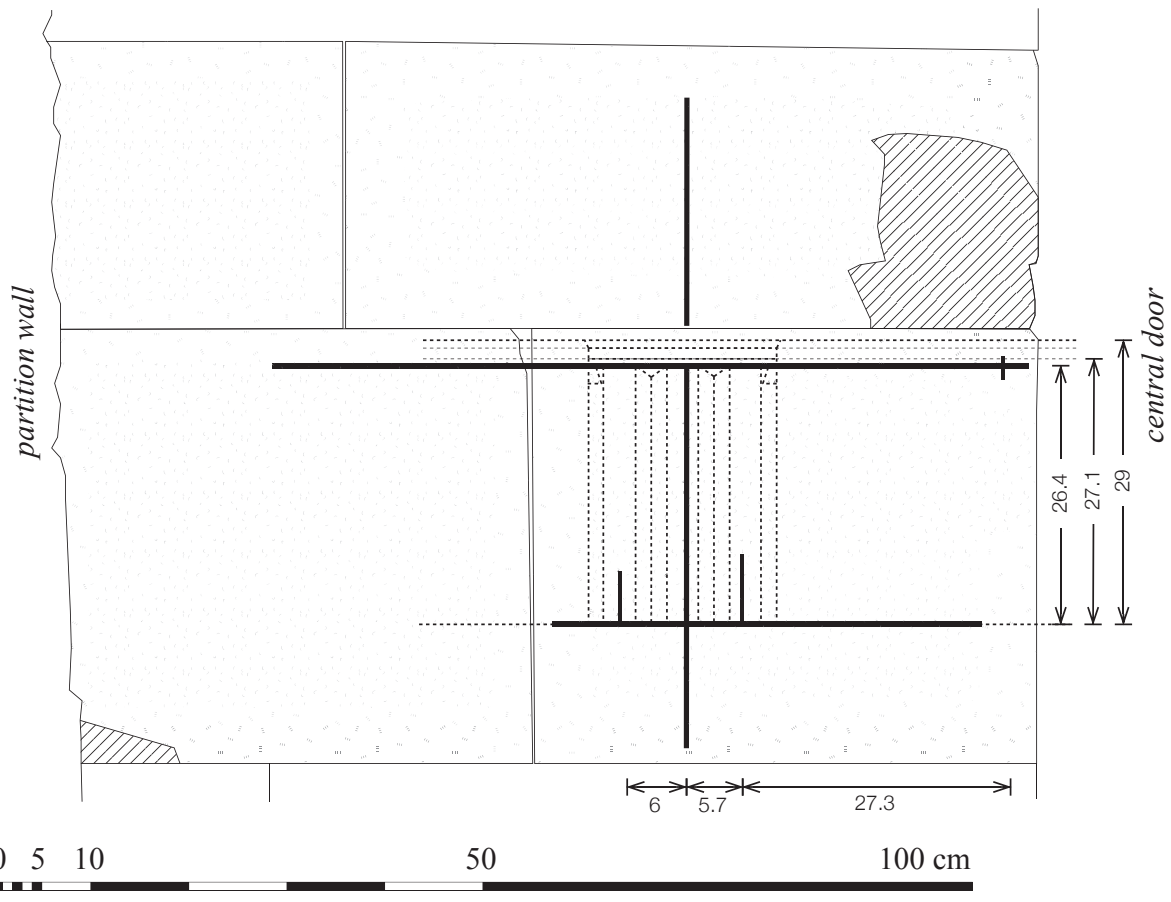

b

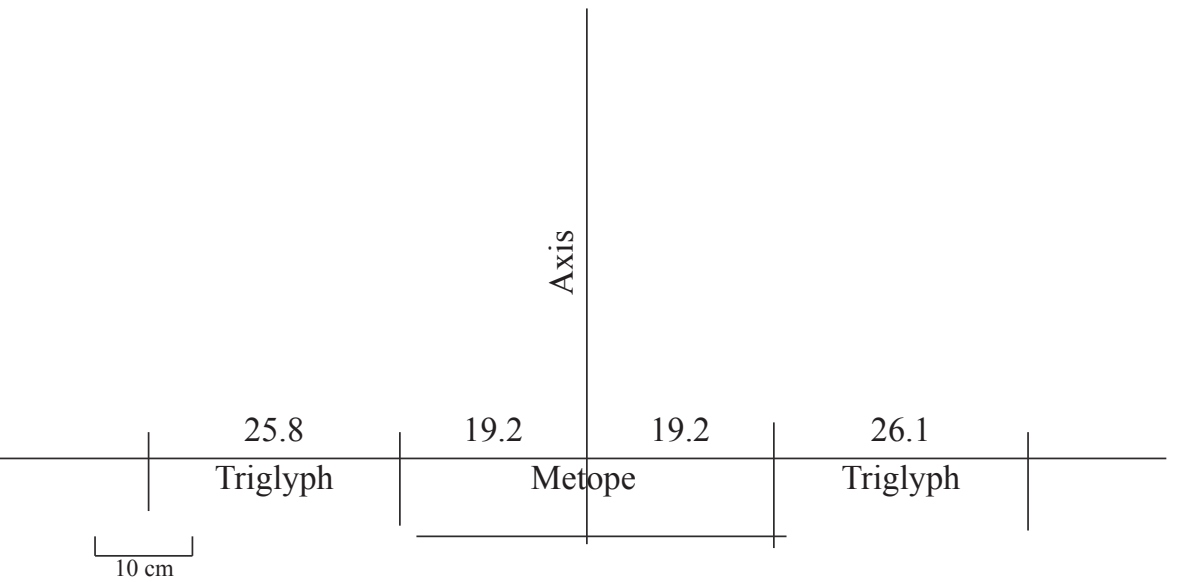

c

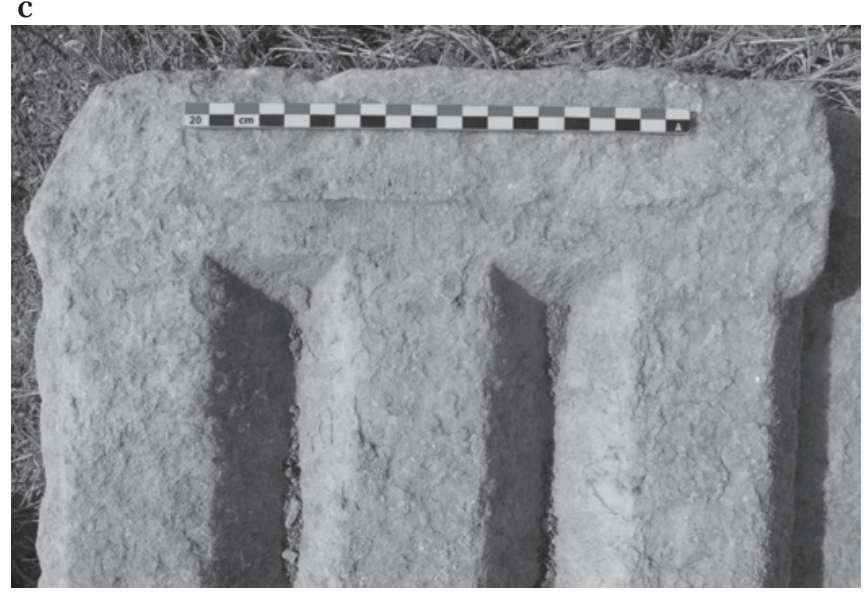

d

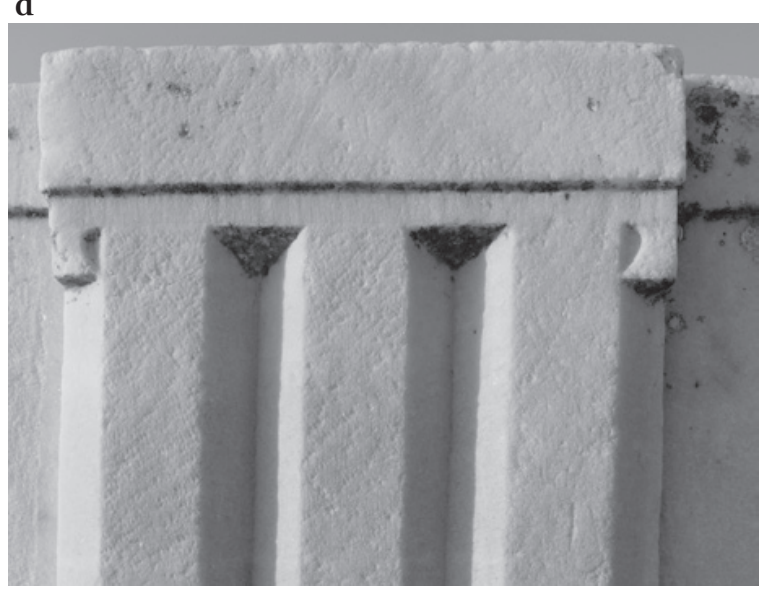

(a) Priene, theatre, blueprint of the Doric frieze of the proskenion (actual thickness of the emphasized lines ca. $0.1 \mathrm{~mm}$ ) with drawing of a triglyph block superimposed (dashed lines); (b) Angista, chamber tomb, blueprint of the plan of the Doric frieze; (c) Delos, Hypostyle Hall, triglyph with a mark for the axis; (d) Agora of the Italians, triglyph with a line above the glyphs (black lines overlaid)

(A) AUTHOR

(B) ADAPTED FROM HOEPFNER 1984

(C)-(D) AUTHOR 

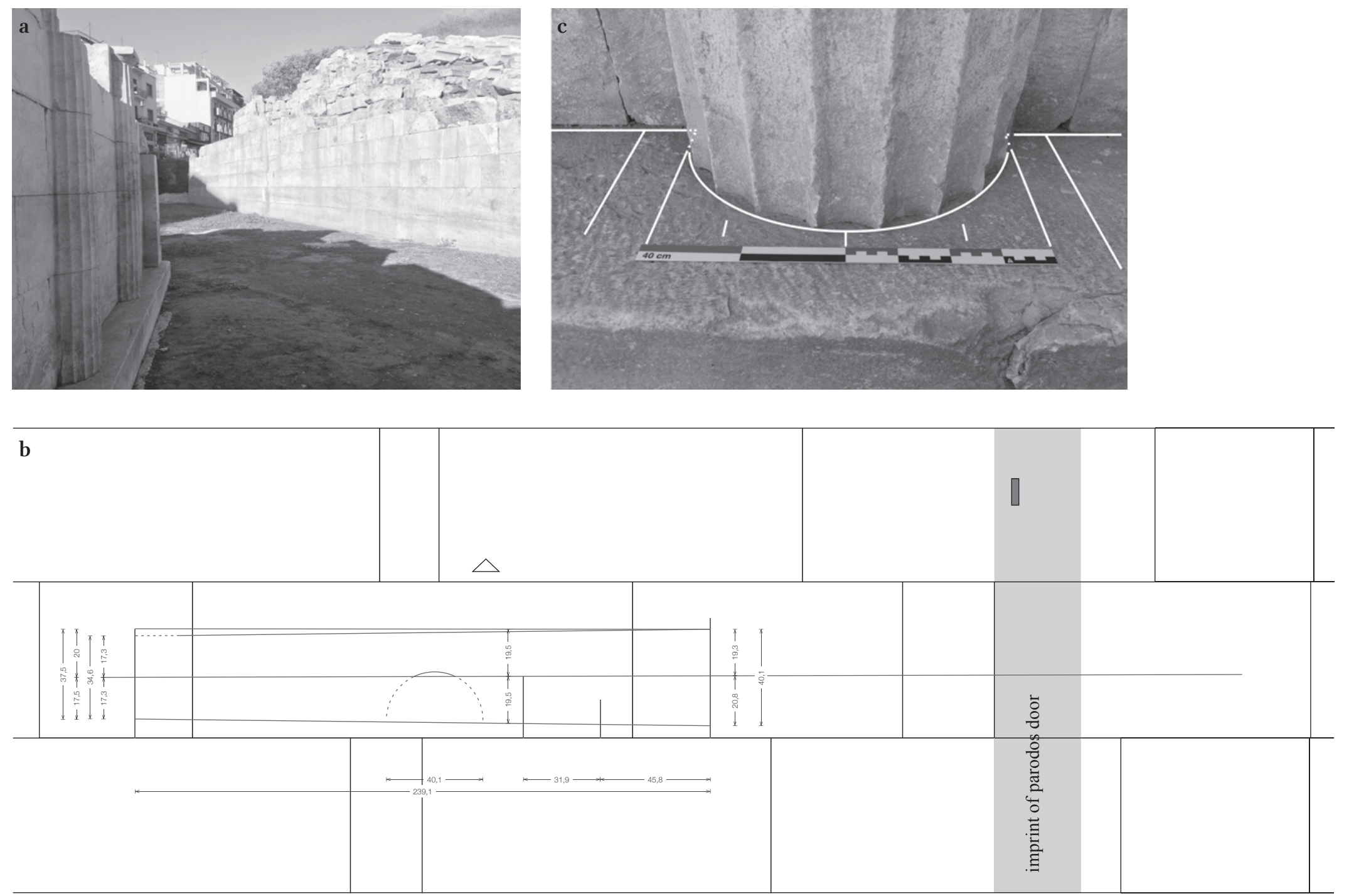

$$
0.5-
$$

FIGURE 3.12A-C Larisa, theatre: (a) proskenion façade in the foreground and western retaining wall in the background; (b) blueprint of the proskenion semi-columns; (c) setting lines on the stylobate of the scene building (white lines overlaid)

PHOTOGRAPHS AND DRAWING ARE BY THE AUTHOR 
the height of the even-numbered (the second and fourth) courses of the pseudo-isodomic masonry, which equals the interval between the two verticals to the right.

Lastly, the imprint of the parodos door can be seen on a part of the drawing: this means the colonnade of the proskenion was made before the parodos door. Although this was not our point here, blueprints not only teach us a great deal about design and architectural practice, but they also provide evidence for the date and the reconstruction of ancient buildings. This multi-faceted information represents a great opportunity for the advancement of Bauforschung.

\section{5}

\section{Conclusions}

We may conclude from these examples that we are now far from the long-established but misconceived notion of Greek architecture as highly normative, repetitive, and conceptual - a model which once led Javary to deny the existence of blueprints. It is today possible to give a substantial answer to this scholar's question, not only because Haselberger's work paved the way for many more discoveries documenting a phenomenon widespread across the Mediterranean and over the ages, but also because our increased knowledge has contributed to changing our way of thinking about ancient architecture. The evidence reveals that a great part of the design was skillfully worked out in the field, during the building, and often on the very walls of the monument being built.

Drawings were used to visualise abstract shapes at a natural scale, to adapt architectural types to specific buildings, and sometimes to test several building options. They helped to determine the general measurements and proportions as well as the details, especially moulding profiles. They represent most generally the final decision, but they can also be places where discussions took place, not only about a slight variation, like the torus on the famous entasis drawing at Didyma, but also about the dimensions, shape, and proportions of architectural forms like the pediment, arches, and seat profile at Miletos. These drawings were the translation, often at a natural scale, of a general sketch, which was either purely conceptual or drawn on perishable material. They follow well-mastered, millimeter-precise Euklidian geometrical constructions. The masons could refer to such patterns in order to mark corresponding guidelines before cutting the stone.

The very few blueprints that have survived to the present day offer us the missing link between theory and practice, by giving us an insight into a well-advanced stage of design and into the ways plans evolved in the construction yard itself. Indeed, once the project of an architect was adopted by the assembly, the building had to be realised in a process that might last for years, decades, or even centuries. When the labour and the financial means were available, it was necessary for the people in charge of the work to give a pragmatic shape to the original ideas-possibly adapting them to the actual conditions - and to issue clear instructions for stonecutting. It is in this context that blueprints became necessary. Blueprints are the proof that "incomplete preliminary planning", as J.J. Coulton (1985) put it, was a common practice, and maybe the rule rather than the exception, in Greek architecture.

\section{List of References}

Altenhöfer, E., 1986: "Das erste römische Bühnengebäude des Theaters von Milet”, in Müller-Wiener, W. (ed.), Milet 18991980. IstMitt Suppl. 31 (Tübingen) 165-73.

Bankel, H., 2013: "Ancient Construction Drawings and New Methods of Documentation: ${ }_{3} \mathrm{D}$ White Light Scanning and 3D Modelling", JRA 21.1: 383-92.

Borchardt, L., 1896: “Altägyptische Werkzeichnungen”, z $\ddot{A} s$ 34: $69-76$.

Bouriant, U., 1895: “(Javary) Question $\mathrm{n}^{\circ} 35$. Sur l'origine historique des épures: Réponse 3", L'intermédiaire des mathématiciens 2: 207-08.

Bouriant, U., 1896: “(Javary) Question $\mathrm{n}^{\circ} 35$. Sur l'origine historique des épures: Réponse 4", L'intermédiaire des mathématiciens 3: 87 .

Brouquier-Reddé, V. \& Gruel, K. (edd.), 2003: Le sanctuaire de Mars Mullo-Allonnes (Sarthe) (Le Mans).

Capelle, J., 2017a: "Les épures du théâtre de Milet: pratiques de chantiers antiques", $B C H$ 141.2: $769-820$.

Capelle, J., 2017b: "Reflectance Transformation Imaging (RTI) et épigraphie”, RAAN: https://raan.hypotheses.org/1326.

Capelle, J., forthcoming (2020): "Une épure de chapiteau corinthien gigantesque gravée sur le parvis du mausolée d'Auguste", RA 69 (2020.1).

Choisy, A., 1894: "(Javary) Question n ${ }^{\circ} 35$. Sur l'origine historique des épures: Réponse 2", L'intermédiaire des mathématiciens 2: 241-42.

Choisy, A., 1904: "Note sur deux épures égyptiennes conservées à Edfou", Journal of the Royal Institute of British Architects 27/08: 503-05.

Čičikova, M., Stoyanova, D. \& Stoyanov, T., 2012: Carskata grobnica s kariatidite kraj selo Sveŝari: 30 godini ot otkrivaneto = The Caryatids Royal Tomb near the Village of Sveshtari: 30 Years since the Discovery (Isperih).

Coulton, J.J., 1985: "Incomplete Preliminary Planning in Greek Architecture: Some New Evidence", in Bommelaer, J.-F. (ed.), 
Le dessin d'architecture dans les sociétés antiques, actes du colloque de Strasbourg, 1984 (Leiden) 103-17.

Daressy, G., 1907: "Un tracé égyptien d'une voûte elliptique", ASAE 8: 237-41.

De Franciscis, A., 1983: "Abozzi per la decorazione dell'anfiteatro campano di S. Maria Capua Vetere", NumAntCl 12: 171-76.

Hanoune, R., 1996: "Un dessin d'architecture au théâtre de «Bulla Regia» (Tunisie)", in Khanoussi, M., Ruggeri, P. \& Vismara, C. (edd.), L'Africa romana, Atti del XI Convegno (Cartagine, 1994). Africa Romana 11 (Ozieri) 911-14.

Haselberger, L., 1980: "Werkzeichnungen am Jüngeren Didymeion-Vorbericht", IstMitt 30: 191-215.

Haselberger, L., 1983: "Bericht über die Arbeit am Jüngeren Apollontempel von Didyma-Zwischenbericht”, IstMitt 33: 90-123.

Haselberger, L., 1986. "Werkzeichnungen des Apollontempels III: das antike Zeichenverfahren", Didyma Wegweiser 23: 2 pp.

Haselberger, L., 1994: "Ein Giebelriß der Vorhalle des Pantheon-die Werkrisse vor dem Augustus-Mausoleum", RM 101: 279-307.

Haselberger, L., 1995: “Deciphering a Roman Blueprint”, Scientific American June 1995: 56-61.

Haselberger, L., 1996: "Die Fronthalle des Pantheon-Ein Werkriss des Dachstuhls?", in Schwandner, E.-L. (ed.), Säule und Gebälk: zu Struktur und Wandlungsprozess griechischrömischer Architektur: Bauforschungskolloquium in Berlin vom 16. bis 18. Juni 1994. DiskAB 6 (Berlin) 182-89.

Hinkel, F.W., 1976: "Erstmals Bauplan einer Pyramide gefunden", Spektrum 6: $30-32$.

Hinkel, F.W., 1980: "Überraschende Entdeckung im Sudan: Die 200o Jahre alte erste Zeichnung einer Pyramide", Altertum 26: 27-33.

Hinkel, F.W., 1981:"Pyramide oder Pyramidenstumpf ?Ein Beitrag zu Fragen der Planung, konstruktiven Baudurchführung und Architektur der Pyramiden von Meroë (Teil A)", zäS 108: $105^{-24}$.

Hoepfner, W., 1984: "Masse-Proportionen-Zeichnungen", in Hoepfner, W. (ed.), Bauplanung und Bautheorie in der Antike. DiskAB 4 (Berlin) 21-23.

Hueber, F., 1998: "Werkrisse, Vorzeichnungen und Meßmarken am Bühnengebäude des Theaters von Aphrodisias", AntW 29.5: 439-45

Inglese, C., 2014: Progetti sulla pietra: Lo studio dei tracciati di cantiere attraverso il rilevamento (Rome).

Jaubert, P. \& Didot, P.-F., 1773: Dictionnaire raisonné universel des arts et métiers, contenant l'histoire, la description, la police des fabriques et manufactures de France \& des pays étrangers (Paris).

Javary, 1894: "Question 35. À quel moment peut-on dire que l'on a commencé à faire des épures, c'est-à-dire des tracés géométriques que l'on s'efforce de rendre aussi exacts que possible ?", L'Intermédiaire des mathématiciens 1: 9-10.

Jomard, E.-F., Lancret, M.A., De Chabrol De Volvic, G.-J.-G., De Rozière, F.-M., De Saint-Genis, A., Jollois, J.-B.-P., De Villiers Du Terrage, É. \& Costaz, L., 1821: Description de l'ÉgypteAntiquités (Paris).

Knackfuß, H., 1908: Milet 1.2: Das Rathaus von Milet (Berlin).

Koenigs, W., 2015: Der Athenatempel von Priene. AF 33 (Wiesbaden).

Krause, C., 1985: "Das Graffito in Terracina”, in Krause, C. (ed.), La prospettiva pittorica, un convegno, Rome, 1980 (Rome) 131-33.

Krauss, F., 1973: Milet IV.1: Das Theater von Milet 1: das hellenistische Theater-der römische Zuschauerbau. (Berlin).

Krauss, F., 1974: "Milet und Didyma: ein Vergleich der Sockelprofilierung an der westlichen Parodoswand des Theaters und den Cellawänden des Apollontempels", in Mansel'e Armağan, тTKY VII, 60 (Ankara) 185-92.

Lapalus, E., 1939: L'agora des Italiens. Délos 19 (Paris).

Manetta, C., Stoyanova, D. \& Luglio, G., 2016: “A New Survey in the Ostrusha Tomb Near Kazanluk. First Results Concerning Architecture and Painting", Bulgarian E-Journal of Archaeology 7: http://be-ja.org.

Petrie, W.M.F., 1888: A Season in Egypt: 1887 (London).

Petronotis, A., 1968: Bauritzlinien und andere Aufschnürungen am Unterbau griechischer Bauwerke in der Archaik und Klassik (Athens).

Petronotis, A., 1972: Zum Problem der Bauzeichnungen bei den Griechen (Athens).

Poulsen, G. \& Vallois, R., 1914: Nouvelles recherches sur la salle hypostyle. Délos 2 (Paris).

Ruiz De La Rosa, J.A., 1987: Trazay simetría de la arquitectura, en la Antigüedad y Medievo (Seville).

Sakarovitch, J., 1998: Épures d'architecture: de la coupe des pierres à la géométrie descriptive XVI ${ }^{e}-X I X^{e}$ siècles (Basel).

Schumacher, A. \& Misiakiewicz,J., 2007:Priene: die Restaurierung des Theaters 1992-1998. Edited by W. Koenigs (Mainz).

Schwandner, E.-L., 1985: "Zu Entwurf, Zeichnung und Maßsystem des älteren Aphaiatempels von Aegina", in Bommelaer, J.-Fr. (ed.), Le dessin d'architecture dans les sociétés antiques, actes du colloque de Strasbourg, 1984 (Leiden) 75-85.

Stanzl, G., 1999: "The Ptolemaion at Limyra and Its Recently Discovered Curvature", in Haselberger, L. (ed.), Appearance and Essence: Refinements of Classical Architecture-Curvature. Proceedings of the Second Williams Symposium on Classical Architecture Held at the University of Pennsylvania, Philadelphia, April 2-4, 1993 (Philadelphia) 155-72.

Tannery, P., 1894: “(Javary) Question $\mathrm{n}^{\circ} 35$. Sur l'origine historique des épures. Réponse 1", L'Intermédiaire des mathématiciens 1: 44.

von Gerkan, A., 1921a: Milet 2.1: Das Stadion (Berlin). 
von Gerkan, A., 1921b: Das Theater von Priene: als Einzelanlage und in seiner Bedeutung für das hellenistische Bühnenwesen (Leipzig).

Weber, U., 2015: "Ein zweiter hellenistischer Naiskos im Apollonheiligtum von Didyma? (Kurzfassung)", in Bachmann, M., Wulf-Rheidt, U., Bänkel, H. \& Schwarting, A. (edd.), Bericht über die 48. Tagung für Ausgrabungswissenschaft und Bauforschung: vom 28. Mai bis 1. Juni 2014 in Erfurt (Stuttgart) 169-171.
Weber, U., Bumke, H., Breder, J., Kaiser, I. \& Reichardt, B., 2015: "Didyma-Bericht über die Arbeiten der Jahre 2010-2013", $A A$ 2015.1: 109-72.

Wiegand, T. \& Schrader, H., 1904: Priene: Ergebnisse der Ausgrabungen und Untersuchungen in den Jahren 1895-1898 (Berlin). 